\title{
CLU wt Allele
}

National Cancer Institute

\section{Source}

National Cancer Institute. CLU wt Allele. NCI Thesaurus. Code C84430.

Human CLU wild-type allele is located within 8p21-p12 and is approximately $36 \mathrm{~kb}$ in length. This allele, which encodes clusterin protein, may play a role in the modulation of complement activation, lipid metabolism and apoptosis. Genetic variation may play a role in Alzheimer's disease. 